\title{
Rh-Catalyzed rearrangement of vinylcyclopropane to 1,3-diene units attached to $\mathbf{N}$-heterocycles
}

\author{
Franca M. Cordero*1, Carolina Vurchio ${ }^{1}$, Stefano Cicchi ${ }^{1}$, Armin de Meijere ${ }^{2}$ \\ and Alberto Brandi ${ }^{* 1}$
}

\section{Full Research Paper}

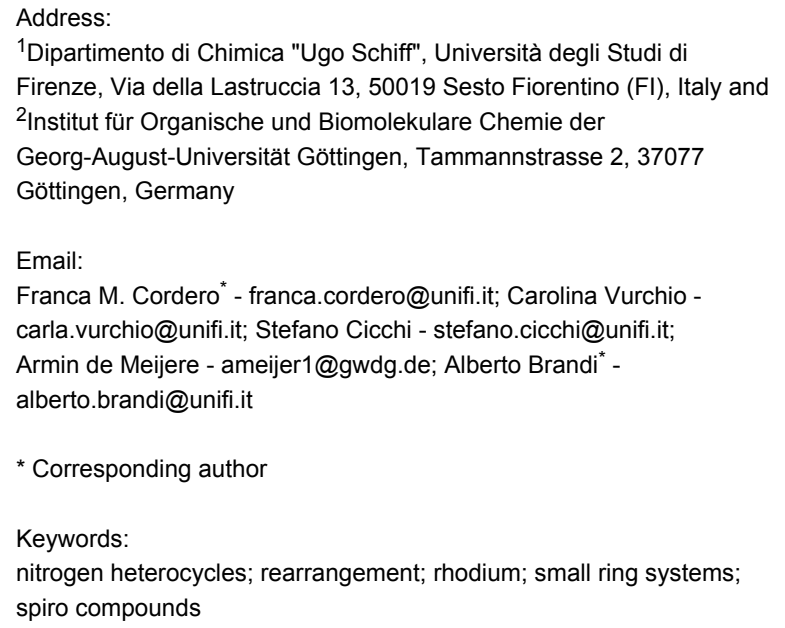

${ }^{1}$ Dipartimento di Chimica "Ugo Schiff", Università degli Studi di Firenze, Via della Lastruccia 13, 50019 Sesto Fiorentino (FI), Italy and ${ }^{2}$ Institut für Organische und Biomolekulare Chemie der Georg-August-Universität Göttingen, Tammannstrasse 2, 37077 Göttingen, Germany

Email:

Franca M. Cordero* - franca.cordero@unifi.it; Carolina Vurchio carla.vurchio@unifi.it; Stefano Cicchi - stefano.cicchi@unifi.it; Armin de Meijere - ameijer1@gwdg.de; Alberto Brandi alberto.brandi@unifi.it

* Corresponding author

\section{Keywords:}

nitrogen heterocycles; rearrangement; rhodium; small ring systems; spiro compounds

\author{
Beilstein J. Org. Chem. 2011, 7, 298-303. \\ doi:10.3762/bjoc.7.39 \\ Received: 21 December 2010 \\ Accepted: 08 February 2011 \\ Published: 09 March 2011 \\ Associate Editor: M. Rueping \\ (c) 2011 Cordero et al; licensee Beilstein-Institut. \\ License and terms: see end of document.
}

\begin{abstract}
Dienes embedded in quinolizidine and indolizidine structures can be prepared in four steps from cyclic nitrones and bicyclopropylidene. The key intermediates $\alpha$-spirocyclopropanated $N$-heterocyclic ketones, generated via a domino 1,3-dipolar cycloaddition/ thermal rearrangement sequence, were converted by Wittig methylenation to the corresponding vinylcyclopropanes (VCPs), which underwent rearrangement to 1,3-dienes in the presence of the Wilkinson $\mathrm{Rh}(\mathrm{I})$ complex under microwave heating. The previously unexplored $\mathrm{Rh}(\mathrm{I})$-catalyzed opening of the VCP moiety embedded in an azapolycyclic system occurs at high temperature $\left(110-130^{\circ} \mathrm{C}\right)$ to afford the corresponding 1,3-dienes in moderate yield (34-53\%).
\end{abstract}

\section{Introduction}

The cyclopropyl group endows many natural and synthetic compounds with a broad spectrum of interesting properties, mainly related to its unusual bonding and inherent ring strain [1-3]. This characteristic confers on molecules containing this moiety high reactivity, especially towards ring expansion and ring-opening transformations. The smallest carbocycle can therefore be considered as a peculiar functional group that can promote unique reactivities and synthetic possibilities [4]. The main obstacle to full exploitation of this chemistry is the difficulty of selectively introducing a cyclopropyl group into a given substrate so that the various specific cyclopropane transformations can be used as a synthetic tool. In recent years we have shown that 1,3-dipolar cycloadditions of nitrones $\mathbf{1}$ to the highly strained alkene bicyclopropylidene (BCP, 2) [5-7] afford spirocyclopropanated isoxazolidines 3 [8,9] which, on heating, rearrange [10] to yield a large variety of spirocyclopropanated 
heterocyclic ketones 4 depending on the nature of the starting nitrone (Scheme 1) [11-17].

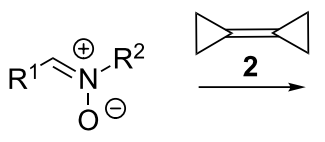

1

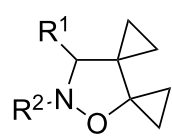

3

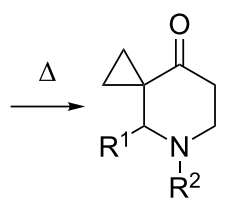

4
Scheme 1: General approach to spirocyclopropanated tetrahydropyridones by 1,3-dipolar cycloaddition/thermal rearrangement.

This rather general and convenient access to spirocyclopropaneannelated heterocyclic ketones $\mathbf{4}$ makes it attractive for the construction of other heterocyclic compounds by selective elaboration of the $\alpha$-oxocyclopropane functionality, for example, to vinylcyclopropane (VCP) by simple Wittig olefination. The rearrangement of VCPs to cyclopentenes and dienes are well known processes [18-25] that occur thermally or under catalysis by various transition metals including $\mathrm{Rh}, \mathrm{Ni}, \mathrm{Pd}, \mathrm{Cu}, \mathrm{Cr}$, Mo, and Fe [26-34]. To date the metal-catalyzed rearrangement of azaheterocyclic VCP has not been reported. In the context of our interest in the VCP chemistry of spirocyclopropaneannelated heterocyclic compounds [35], we started to investigate some metal-catalyzed rearrangements. The first choice was the readily available so-called Wilkinson catalyst $\mathrm{Rh}\left(\mathrm{PPh}_{3}\right)_{3} \mathrm{Cl}$, because of its documented efficiency in catalyzing the rearrangement [26] and of the possibility to extend its use to other interesting transformations, such as the $[5+2]$ cycloadditions of vinylcyclopropanes to alkynes developed by Wender and co-workers [36,37]. It is known, that rhodium-catalyzed rearrangements of unactivated VCPs, without any functional substituent, usually afford dienes. In order to evaluate the influence of the $N$-heterocyclic system on the rearrangement, some model VCPs were generated by Wittig olefination of the $\alpha$-oxocyclopropane group of functionalized oligocyclic spirocyclopropane-tetrahydropyridones and converted into the corresponding 1,3-dienes by treatment with $\mathrm{Rh}\left(\mathrm{PPh}_{3}\right)_{3} \mathrm{Cl}$.

\section{Results and Discussion}

The tetrahydropyridones employed in this study were prepared according to published procedures with slight modifications. In particular, oxidation of the tetrahydroquinoline 5 with oxone [38] afforded the nitrone 6 [39-41] in 66\% yield (Scheme 2, see Supporting Information File 1 for full experimental data). Treatment of 6 (1.2-1.7 equiv) with BCP (2) in xylenes at $125^{\circ} \mathrm{C}$ for $64 \mathrm{~h}$ directly afforded the $\alpha$-oxocyclopropane derivative 8 [13] (51-72\% yield) along with a minor amount of the open-chain isomer 9 (20-23\% yield).
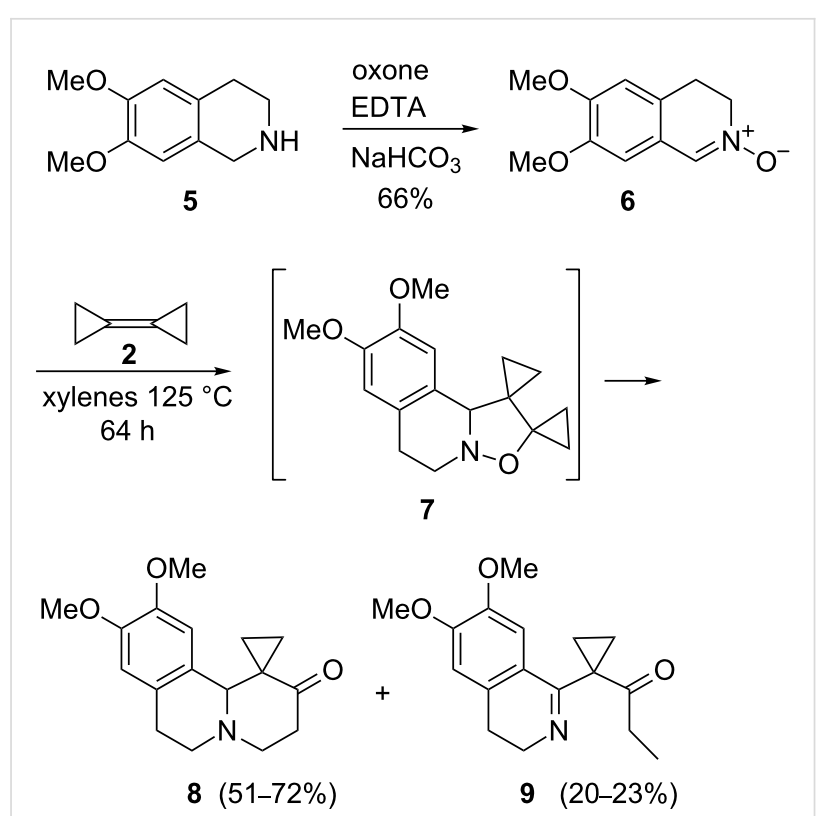

Scheme 2: Synthesis of tetrahydrospiro[cyclopropane-1,1'(2' $\left.H, 6^{\prime} H\right)$ pyrido[2,1-a]isoquinolin]-2'-one 8 .

The open-chain isomer 9 is derived from a rarely observed 1,5hydrogen shift in the cyclopropanated 1,6-diradical intermediate, which in this case is probably facilitated by the enhanced mobility of the benzylic hydrogen and by the formation of the conjugationally stabilized imine 9 [11].

The 1,3-dipolar cycloaddition/thermal rearrangement domino reaction of BCP (2) with the enantiopure nitrone 10 [42] derived from L-tartaric acid was complete within only $1.5 \mathrm{~h}$ at $120-125{ }^{\circ} \mathrm{C}$ under microwave (MW) heating and afforded the oxospirocyclopropanes anti-12 and syn-12 in 55\% overall yield along with the 1,5-hydrogen shift product 13 (13\%) (Scheme 3, see Supporting Information File 1 for full experimental data). The two diastereomeric indolizidinones anti-12 and syn-12 are formed by the thermal rearrangement of the cycloadducts anti(3-t-BuO)-11 and syn-(3-t-BuO)-11, respectively.

Wittig olefination of ketones 8, anti-12 and $\mathbf{1 6}$ [43] with $\mathrm{MePPh}_{3} \mathrm{Br} / t$-BuOK in THF at room temperature gave the VCPs 14, 15, and 17 in good yields (53-96\%) (Scheme 4, see Supporting Information File 1 for full experimental data). The configuration was retained under the reaction conditions in compounds 15 and 17, as ascertained by the unique set of ${ }^{1} \mathrm{H}$ NMR signals in the crude reaction mixture.

The tricyclic compound $\mathbf{1 4}$ was then treated with a catalytic amount of $\mathrm{Rh}\left(\mathrm{PPh}_{3}\right)_{3} \mathrm{Cl}$ (Table 1). In toluene at room temperature no reaction occurred, but on heating under reflux $\left(110^{\circ} \mathrm{C}\right)$ or at $130{ }^{\circ} \mathrm{C}$ in a microwave (MW) oven a rearrangement 


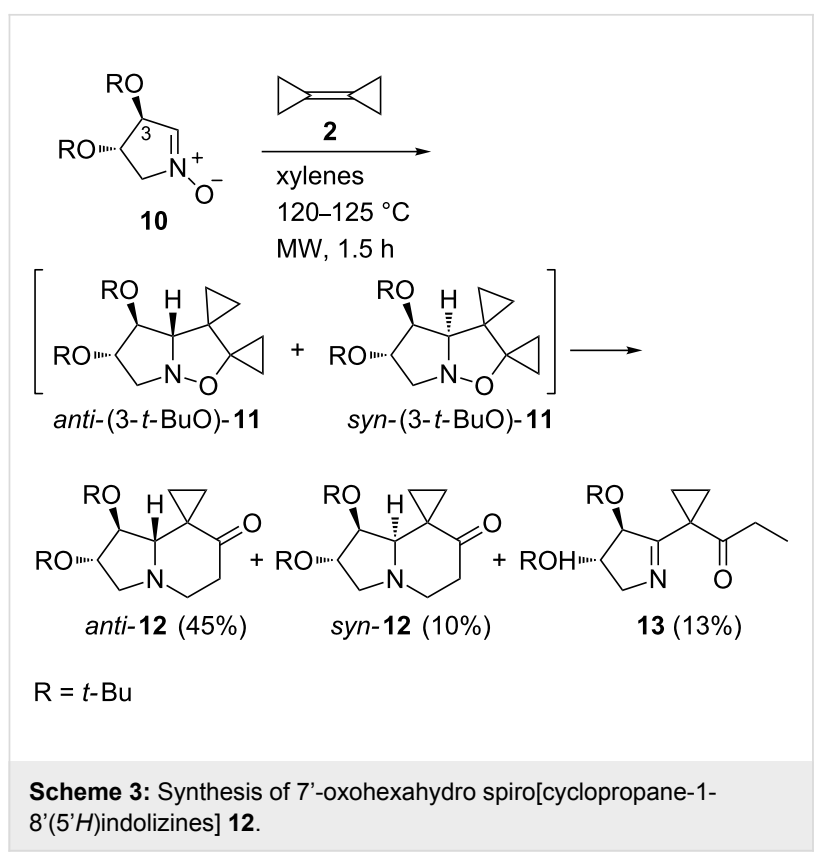

occurred leading to a main product assigned as the diene $\mathbf{1 8}$ and a mixture of the two diastereomers $(E)$ - and $(Z)-19$. No trace of the cyclopentene-annelation product was observed in the reaction mixture. In refluxing toluene, the reaction was quite slow and after $15 \mathrm{~h}$ in the presence of $5 \mathrm{~mol} \%$ of catalyst, a considerable amount of starting material still remained. Even after the addition of a second portion of the catalyst and further heating at $110^{\circ} \mathrm{C}$ for $18 \mathrm{~h}$, the conversion was incomplete, and

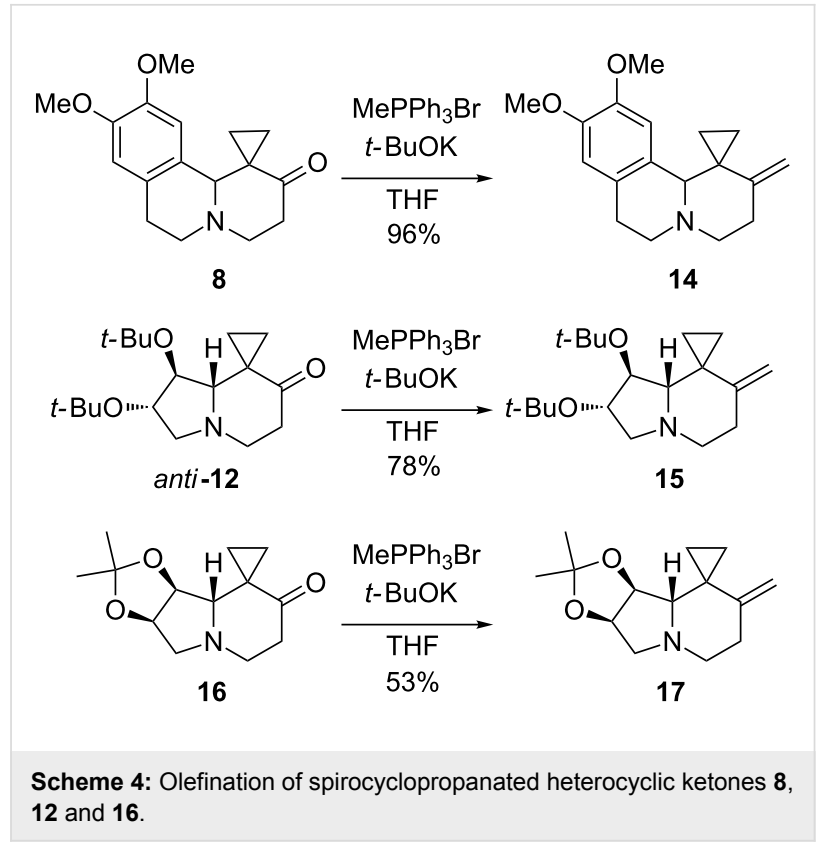

the VCP 14 was recovered in $18 \%$ yield after chromatography (Table 1, entry 1). The dienes $\mathbf{1 8}$ and $\mathbf{1 9}$ were obtained in 35\% overall yield (43\% yield based on converted 14). The VCP was completely consumed after $58 \mathrm{~h}$ at $110{ }^{\circ} \mathrm{C}$ by adding three portions of the catalyst ( $5 \mathrm{~mol} \%$ each at 0,24 and $40 \mathrm{~h}$, respectively) (Table 1 , entry 2 ). In this case, the products were obtained in a lower yield (28\%) probably because they partially decomposed upon prolonged heating. The reaction carried out

Table 1: Rearrangement of VCP 14 catalyzed by $\mathrm{Rh}\left(\mathrm{PPh}_{3}\right)_{3} \mathrm{Cl}$.<smiles>C=C1CCN2CCc3cc(OC)c(OC)cc3C2C12CC2</smiles>

14<smiles>C=CC1=C(C)CCN2CCc3cc(OC)c(OC)cc3C12</smiles>

18<smiles>C=C1CCN2CCc3cc(OC)c(OC)cc3C2C1=CC</smiles>

$(E)-19$ and $(Z)-19$

\begin{tabular}{|c|c|c|c|c|c|c|}
\hline Entry & $\operatorname{Rh}(I)(\%)$ & Temp. $^{a}\left({ }^{\circ} \mathrm{C}\right)$ & Time & Conv. ${ }^{b}(\%)$ & $18 / 19$ & Yield $^{\mathrm{C}}(\%)$ \\
\hline 1 & $5+5^{d}$ & 110 & $15+18 h$ & 82 & $2.5: 1$ & $35(43)$ \\
\hline 2 & $5+5+5^{e}$ & 110 & $24+16+18 h$ & 100 & $1.1: 1$ & $28(28)$ \\
\hline 3 & 5 & $130(\mathrm{MW})$ & $1 \mathrm{~h} 30 \mathrm{~min}$ & 62 & $4.5: 1$ & $46(74)$ \\
\hline 4 & 10 & 130 (MW) & $2 \mathrm{~h} 20 \mathrm{~min}$ & 78 & $1.4: 1$ & $59(75)$ \\
\hline 5 & $5+5^{d}$ & $130(\mathrm{MW})$ & $3+4 h$ & 100 & & $\operatorname{dec}^{f}$ \\
\hline 69 & $5+5^{d}$ & 160 (MW) & $2+1 h$ & $72^{\mathrm{h}}$ & $3.3: 1$ & $n^{i}$ \\
\hline $7^{\mathrm{j}}$ & 5 & $130(\mathrm{MW})$ & $2 \mathrm{~h}$ & $55^{\mathrm{h}}$ & $3: 1$ & nd $d^{i}$ \\
\hline $8^{k}$ & 10 & $130(\mathrm{MW})$ & $5 \mathrm{~h} 30 \mathrm{~min}$ & 100 & $1: 1$ & $46(46)$ \\
\hline
\end{tabular}

aMW: the reaction was carried out in a CEM Discover microwave reactor with IR temperature monitoring. ${ }^{\mathrm{b}}$ Based on recovered starting material after chromatography. ${ }^{c}$ Overall yield after chromatography on $\mathrm{SiO}_{2}$. The yield based on converted VCP is given in parentheses. ${ }^{\mathrm{d}} \mathrm{The}$ catalyst was added in

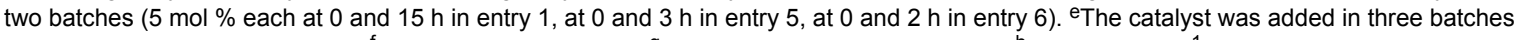
$\left(5 \mathrm{~mol} \%\right.$ each at 0,24 and $40 \mathrm{~h}$ ). ${ }^{\mathrm{f}}$ Decomposition products. ${ }^{9}$ The reaction was run in xylenes. ${ }^{\mathrm{h}}$ Determined by ${ }^{1} \mathrm{H}$ NMR analysis of the crude reaction mixture. iNot determined. ${ }^{\mathrm{j}} 5 \%$ AgOTf was added. ${ }^{\mathrm{k}} 5 \%$ TFE was added. 
at $130{ }^{\circ} \mathrm{C}$ in an MW reactor for shorter times actually gave better yields (Table 1, entries 3 and 4). The best result with a conversion of $78 \%$ and $59 \%$ yield was achieved by heating a mixture of the VCP 14 and $10 \mathrm{~mol} \%$ of the catalyst in toluene at $130{ }^{\circ} \mathrm{C}$ for $140 \mathrm{~min}$ (Table 1 , entry 4 ). When the reaction was allowed to continue until all the starting material was completely consumed led to complete decomposition of the products (Table 1 , entry 5 ). Higher temperatures $\left(160^{\circ} \mathrm{C}\right.$ in xylenes) or the addition of AgOTf [44] did neither improve the conversion rate nor the yield of the rearrangement products (Table 1, entries 6 and 7). A slight improvement was achieved by addition of trifluoroethanol (TFE, $5 \%$ of the total volume) as a co-solvent [45]. Under these conditions, the conversion of the VCP was complete after $5.5 \mathrm{~h}$ at $130{ }^{\circ} \mathrm{C}$, and the dienes $\mathbf{1 8}$ and 19 were obtained in a $1: 1$ ratio in $46 \%$ overall yield after chromatography (Table 1, entry 8 , see Supporting Information File 1 for full experimental data).

The collected data show that longer reaction times significantly influence the product ratio in favour of the dienes $\mathbf{1 9}$ (Table 1). These results are in accord with an isomerization of $\mathbf{1 8}$ into $\mathbf{1 9}$ under the reaction conditions. However, in the absence of the catalyst, heating of diene $\mathbf{1 8}$ under otherwise identical conditions did not induce any isomerization of $\mathbf{1 8}$ to $\mathbf{1 9}$, which confirms that Rh also catalyzes the 1,5-hydrogen shift in 18.

The structure assignment was easily made on the basis of ${ }^{1} \mathrm{H}$ NMR data. In particular, the diene $\mathbf{1 8}$ showed the typical signals of an exocyclic vinyl substituent $\left(\delta 7.00\left(=\mathrm{C} H_{v}\right), 5.17\right.$ $\left(=\mathrm{CH} H_{\text {cis }}\right), 5.17\left(=\mathrm{CH} H_{\text {trans }}\right) \mathrm{ppm} ; J_{\text {trans }}=17.5, J_{\text {cis }}=$ $11.3 \mathrm{~Hz})$. Irradiation of $11 \mathrm{~b}-\mathrm{H}(\delta 4.76 \mathrm{ppm})$ produced a positive NOE on the olefinic $H_{\text {trans }}$ whereas irradiation of $=\mathrm{CH}$ resulted in enhancement of the $2-\mathrm{CH}_{3}$ signal $(\delta 1.87 \mathrm{ppm})$ suggesting a preferred $s$-trans conformation for the diene moiety in solution (Figure 1).

The ${ }^{1} \mathrm{H}$ NMR spectra of the dienes 19 showed a quartet in the region of olefinic due to the resonance of the proton $\mathrm{H}_{\mathrm{c}}$ coupled with the methyl group ( $\delta 5.29$ and $\left.5.96 \mathrm{ppm},{ }^{3} J=6.9-7.0 \mathrm{~Hz}\right)$ and two signals due to the methylene protons $\mathrm{H}_{\mathrm{a}}$ and $\mathrm{H}_{\mathrm{b}}(\delta 5.06$ and $4.75 ; 4.89$ and $4.65 \mathrm{ppm},{ }^{2} J=2.3-2.1 \mathrm{~Hz}$ ).

The $E$ - and $Z$-configuration of the dienes 19 was determined by NOESY 1D NMR spectroscopy. In the major compound $(E)$-19, irradiation of the olefinic $\mathrm{H}_{\mathrm{b}}(\delta 4.75 \mathrm{ppm})$ gave enhancement of the ethylidene methyl group $(\delta 1.76 \mathrm{ppm})$, and irradiation of $\mathrm{H}_{\mathrm{c}}$ $(\delta 5.29 \mathrm{ppm})$ showed enhancement at $11-\mathrm{H}$ and $11 \mathrm{~b}-\mathrm{H}(\delta 6.56$ and $4.41 \mathrm{ppm})$. For the isomer $(Z)-19$, irradiation of $\mathrm{H}_{\mathrm{c}}$ ' ( $\delta 5.96 \mathrm{ppm})$ gave enhancement of $\mathrm{H}_{\mathrm{b}},(\delta 4.89 \mathrm{ppm})$ and an NOE interaction was present between the methyl group and

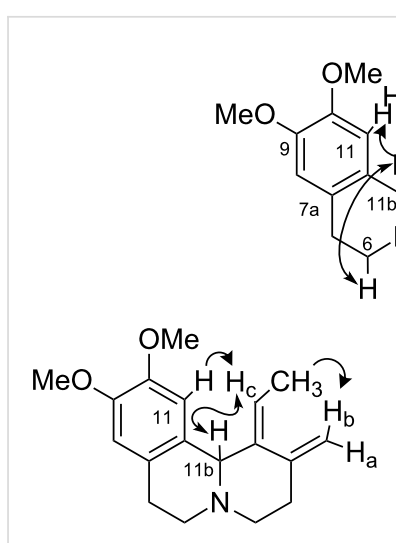

(E)- 19

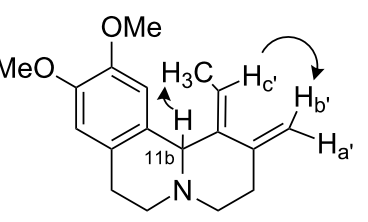

(Z)-19
Figure 1: Key NOE interactions. 18: 11b-H/11- $\mathrm{H}, 11 \mathrm{~b}-\mathrm{H} / 6-\mathrm{H}, 11 \mathrm{~b}-\mathrm{H} / \mathrm{H}_{\mathrm{t}}$, $\mathrm{H}_{\mathrm{v}} / 2-\mathrm{CH}_{3} ; \mathrm{E}-19: \mathrm{H}_{\mathrm{b}} / \mathrm{CH}_{3}, \mathrm{H}_{\mathrm{c}} / 11 \mathrm{~b}-\mathrm{H}, \mathrm{H}_{\mathrm{C}} / 11-\mathrm{H} ; \mathrm{Z}-19: \mathrm{H}_{\mathrm{b}}, \mathrm{H}_{\mathrm{c}^{\prime}}, 11 \mathrm{~b}-\mathrm{H} / \mathrm{CH}_{3}$.

$11 \mathrm{~b}-\mathrm{H}(\delta 5.02 \mathrm{ppm})$ in agreement with the assigned configuration (Figure 1).

The VCPs 15 and 17 were completely consumed on heating in toluene in a $\mathrm{MW}$ oven at $130{ }^{\circ} \mathrm{C}$ for $3 \mathrm{~h}$ and $110{ }^{\circ} \mathrm{C}$ for $3.5 \mathrm{~h}$, respectively, in the presence of $\mathrm{Rh}\left(\mathrm{PPh}_{3}\right)_{3} \mathrm{Cl}(10 \%)$ and TFE (5\%). In these cases, dienes $\mathbf{2 0}$ and $\mathbf{2 1}$ were obtained in 53 and $34 \%$ yield, respectively, as the sole reaction products (Scheme 5, see Supporting Information File 1 for full experimental data). Their structures were assigned analogously as before. Compounds $\mathbf{2 0}$ and $\mathbf{2 1}$ were found to be unstable upon standing for prolonged periods, even at low temperatures. This explains the low isolated yields in their syntheses.

Analogously to other Rh(I)-catalyzed VCP rearrangements $[46,47]$, the mechanism of the rearrangement likely involves insertion of the $\mathrm{Rh}(\mathrm{I})$ species into the cyclopropane ring of the VCP system, with or without incorporation of the double

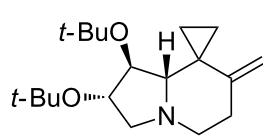

15

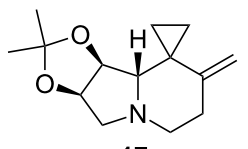

17

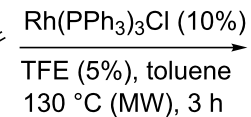
$53 \%$

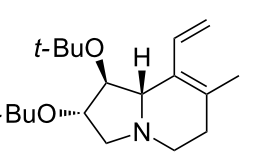

20
Scheme 5: Rearrangement of VCPs 15 and 17 catalyzed by $\mathrm{Rh}\left(\mathrm{PPh}_{3}\right)_{3} \mathrm{Cl}$. 
bond to form the intermediates $\mathbf{C}$ which can undergo metal hydride elimination or 1,3-hydride migration to the rhodium to give, respectively, the allyl- and alkylrhodium(III) hydride complexes $\mathbf{D}$ and $\mathbf{F}$. Metal extrusion by reductive elimination leads to the observed dienes and regeneration of the catalyst (Scheme 6).

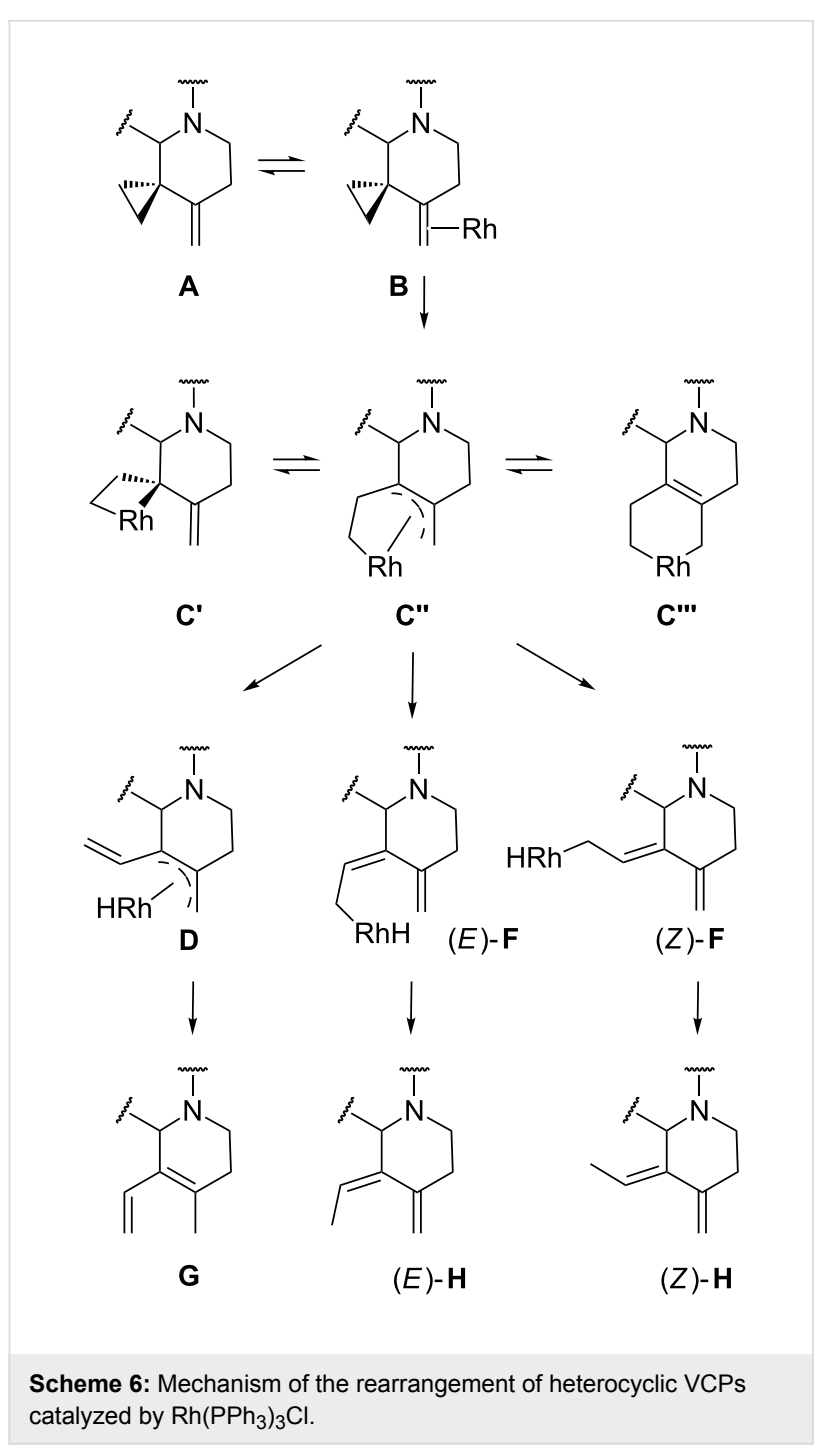

\section{Conclusion}

Azaheterocycles 14, 15 and 17 containing a spiro-annelated VCP moiety have been synthesized starting from cyclic nitrones and BCP by a three-step two-pot sequence consisting of a 1,3dipolar cycloaddition, thermal rearrangement and Wittig methylenation. These compounds in the presence of the Wilkinson $\mathrm{Rh}(\mathrm{I})$ complex at high temperatures $\left(110-130^{\circ} \mathrm{C}\right)$ under MW heating underwent a slow rearrangement to afford the corresponding azaheterocycles containing 1,3-diene units in moderate yields. The rearrangement produced mixtures of isomeric dienes from benzoquinolizidine $\mathbf{1 4}$ and was regioselec- tive in the case of indolizidines $\mathbf{1 5}$ and $\mathbf{1 7}$, showing that the Wilkinson $\mathrm{Rh}(\mathrm{I})$ catalyst is also capable of inducing the VCP rearrangement in the presence of strongly nucleophilic azaheterocycles. Accordingly, new functionalised heterocyclic compounds can be produced by the straightforward methodology based on nitrones and bicyclopropylidene.

\section{Supporting Information}

Supporting information features experimental procedures and spectroscopic data.

\section{Supporting Information File 1 \\ Experimental part. \\ [http://www.beilstein-journals.org/bjoc/content/ \\ supplementary/1860-5397-7-39-S1.pdf]}

\section{Acknowledgements}

Mr. Reent Michel, a Sokrates-exchange student from the GeorgAugust-Universität Göttingen (Germany), is acknowledged for his partial contribution to this work. Ente Cassa di Risparmio di Firenze (Florence, Italy) is acknowledged for partial financial support of a fellowship for C. V. Ministry of University and Research (MIUR Rome-Italy) is acknowledged for financial support (PRIN project).

\section{References}

1. de Meijere, A. Angew. Chem., Int. Ed. Engl. 1979, 18, 809-826. doi:10.1002/ange.19790911104

2. Salaün, J. In The Chemistry of the Cyclopropyl Group; Patai, S.; Rappoport, Z., Eds.; Wiley: New York, 1987; pp 809-878.

3. Salaün, J. Top. Curr. Chem. 2000, 207, 1-67. doi:10.1007/3-540-48255-5_1

4. de Meijere, A., Ed. Houben-Weyl, Carbocyclic Three-Membered Ring Compounds; Thieme: Stuttgart, 1997; Vol. E17.

5. Brandi, A.; Goti, A. Chem. Rev. 1998, 98, 589-636. doi:10.1021/cr940341t

6. de Meijere, A.; Kozhushkov, S. I. Eur. J. Org. Chem. 2000, 3809-3822. doi:10.1002/1099-0690(200012)2000:23<3809::AID-EJOC3809>3.0.C $\mathrm{O} ; 2-\mathrm{X}$

7. de Meijere, A.; Kozhushkov, S. I. Chem. Rev. 2000, 100, 93-142. doi:10.1021/cr960153y

8. Brandi, A.; Cordero, F. M.; De Sarlo, F.; Goti, A.; Guarna, A. Synlett 1993, 1-8. doi:10.1055/s-1993-22329

9. Goti, A.; Cordero, F. M.; Brandi, A. Top. Curr. Chem. 1996, 178, 1-97. doi:10.1007/3-540-60495-2_1

10. Brandi, A.; Cicchi, S.; Cordero, F. M.; Goti, A. Chem. Rev. 2003, 103, 1213-1269. doi:10.1021/cr010005u

11. Goti, A.; Anichini, B.; Brandi, A.; Kozhushkov, S. I.; Gratkowski, C.; de Meijere, A. J. Org. Chem. 1996, 61, 1665-1672. doi:10.1021/jo951838I

12. Goti, A.; Anichini, B.; Brandi, A.; de Meijere, A.; Citti, L.; Nevischi, S. Tetrahedron Lett. 1995, 36, 5811-5814. doi:10.1016/0040-4039(95)01103-O 
13. Zorn, C.; Anichini, B.; Goti, A.; Brandi, A.; Kozhushkov, S. I.; de Meijere, A.; Citti, L. J. Org. Chem. 1999, 64, 7846-7855. doi:10.1021/jo990873f

14. Anichini, B.; Goti, A.; Brandi, A.; Kozhushkov, S. I.; de Meijere, A Synlett 1997, 25-26. doi:10.1055/s-1997-684

15. Marradi, M.; Brandi, A.; Magull, J.; Schill, H.; de Meijere, A. Eur. J. Org. Chem. 2006, 5485-5494. doi:10.1002/ejoc.200600417

16. Zorn, C.; Goti, A.; Brandi, A.; Johnsen, K.; Noltemeyer, M.; Kozhushkov, S. I.; de Meijere, A. J. Org. Chem. 1999, 64, 755-763. doi:10.1021/jo981366l

17. Revuelta, J.; Cicchi, S.; Faggi, C.; Kozhushkov, S. I.; de Meijere, A.; Brandi, A. J. Org. Chem. 2006, 71, 2417-2423. doi:10.1021/jo052564x

18. Neureiter, N. P. J. Org. Chem. 1959, 24, 2044-2046. doi:10.1021/jo01094a621

19. Overberger, C. G.; Borchert, A. E. J. Am. Chem. Soc. 1960, 82, 1007-1008. doi:10.1021/ja01489a069

20. Flowers, M. C.; Frey, H. M. J. Chem. Soc. 1961, 82, 3547-3548.

21. Hudlicky, T.; Becker, D. A.; Fan, R. L.; Kozhushkov, S. I. In Houben-Weyl; de Meijere, A., Ed.; Thieme: Stuttgart, 1997; Vol. E17c, pp 2538-2565.

22. Hudlicky, T.; Fan, R. L.; Reed, J. W.; Gadamasetti, K. G. Org. React. 1992, 41, 1-133. doi:10.1002/0471264180.or041.01

23. Hudlicky, T.; Reed, J. W. In Comprehensive Organic Synthesis-Selectivity, Strategy \& Efficiency in Modern Organic Chemistry; Trost, B. M.; Fleming, I.; Paquette, L. A., Eds.; Pergamon Press: Oxford, 1991; Vol. 5, pp 899-970.

24. Baldwin, J. E. Chem. Rev. 2003, 103, 1197-1212. doi:10.1021/cr010020z

25. Wang, S. C.; Tantillo, D. J. J. Organomet. Chem. 2006, 691, 4386-4392. doi:10.1016/j.jorganchem.2005.12.052

26. Hayashi, M.; Ohmatsu, T.; Meng, Y.-P.; Saigo, K. Angew. Chem., Int. Ed. 1998, 110, 877-879. doi:10.1002/(SICI)1521-3773(19980403)37:6<837::AID-ANIE837>3.0. CO;2-R

27. Zuo, G.; Louie, J. Angew. Chem., Int. Ed. 2004, 43, 2277-2279. doi:10.1002/anie.200353469 Angew. Chem. 2004, 116, 2327-2329. doi:10.1002/ange.200353469

28. Hiroi, K.; Arinaga, Y. Tetrahedron Lett. 1994, 35, 153-156. doi:10.1016/0040-4039(94)88188-X

29. Morizawa, Y.; Oshima, K.; Nozaki, H. Tetrahedron Lett. 1982, 23 , 2871-2874. doi:10.1016/S0040-4039(00)88436-1

30. Davies, H. M. L.; Hu, B. J. Org. Chem. 1992, 57, 3186-3190. doi:10.1021/jo00037a041

31. Hudlicky, T.; Koszyk, F. J.; Kutchan, T. M.; Sheth, J. P. J. Org. Chem 1980, 45, 5020-5027. doi:10.1021/jo01313a003

32. Buchert, M.; Reissig, H.-U. Liebigs Ann. 1996, 2007-2013. doi:10.1002/jlac.199619961210

33. Davies, H. M. L.; Hu, B. Tetrahedron Lett. 1992, 33, 453-456.

34. Doyle, M. P.; van Leusen, D. J. Org. Chem. 1982, 47, 5326-5339. doi:10.1021/jo00148a020

35. Brandi, A.; Cicchi, S.; Brandl, M.; Kozhushkov, S. I.; de Meijere, A. Synlett 2001, 433-435. doi:10.1055/s-2001-11396 Example for a study of the thermal VCP to cyclopentene rearrangement in such compounds.

36. Wender, P. A.; Takahashi, H.; Witulski, B. J. Am. Chem. Soc. 1995, 117, 4720-4721. doi:10.1021/ja00121a036

37. Wegner, H. A.; de Meijere, A.; Wender, P. A. J. Am. Chem. Soc. 2005, 127, 6530-6531. doi:10.1021/ja043671w
38. Sánchez-Izquierdo, F.; Blanco, P.; Busqué, F.; Alibés, R.; de March, P.; Figueredo, M.; Font, J.; Parella, T. Org. Lett. 2007, 9 , 1769-1772. doi:10.1021/ol070486p

39. Brandi, A.; Garro, S.; Guarna, A.; Goti, A.; Cordero, F.; De Sarlo, F. J. Org. Chem. 1988, 53, 2430-2434. doi:10.1021/jo00246a008

40. Yamazaki, S. Bull. Chem. Soc. Jpn. 1997, 70, 877-883. doi:10.1246/bcsj.70.877

41. Zhao, B.-X.; Yu, Y.; Eguchi, S. Org. Prep. Proced. Int. 1997, 29 , 185-194. doi:10.1080/00304949709355182

42. Cicchi, S.; Corsi, M.; Goti, A. J. Org. Chem. 1999, 64, 7243-7245. doi:10.1021/jo990417r

43. Revuelta, J.; Cicchi, S.; de Meijere, A.; Brandi, A. Eur. J. Org. Chem. 2008, 1085-1091. doi:10.1002/ejoc.200700912

44. Wender, P. A.; Dyckman, A. J. Org. Lett. 1999, 1, 2089-2092. doi:10.1021/ol991171f

45. Wender, P. A.; Barzilay, C. M.; Dyckman, A. J. J. Am. Chem. Soc. 2001, 123, 179-180. doi:10.1021/ja0021159

46. Salomon, R. G.; Salomon, M. F.; Kachinski, J. L. C. J. Am. Chem. Soc. 1977, 99, 1043-1054. doi:10.1021/ja00446a012

47. Salomon, M. F.; Salomon, R. G. J. Chem. Soc., Chem. Commun. 1976, 89-90. doi:10.1039/C39760000089

\section{License and Terms}

This is an Open Access article under the terms of the Creative Commons Attribution License (http://creativecommons.org/licenses/by/2.0), which permits unrestricted use, distribution, and reproduction in any medium, provided the original work is properly cited.

The license is subject to the Beilstein Journal of Organic Chemistry terms and conditions:

(http://www.beilstein-journals.org/bjoc)

The definitive version of this article is the electronic one which can be found at: doi:10.3762/bjoc.7.39 